Cahiers $d u$ MONDE RUSSE

\section{Cahiers du monde russe}

Russie - Empire russe - Union soviétique et États indépendants

48/2-3 | 2007

Les résonances de 1905

\title{
Partija socialistov-revoljucionerov vo vremja i posle revoljusii 1905-1907 gg.
}

\section{Konstantin N. MOROZOV}

\section{OpenEdition \\ Journals}

Édition électronique

URL : https://journals.openedition.org/monderusse/9005

DOI : 10.4000/monderusse.9005

ISSN : $1777-5388$

\section{Éditeur}

Éditions de l'EHESS

\section{Édition imprimée}

Date de publication : 15 avril 2007

Pagination : 301-330

ISBN : 978-2-7132-2147-7

ISSN : $1252-6576$

Référence électronique

Konstantin N. MOROZOV, «Partija socialistov-revoljucionerov vo vremja i posle revoljusii 1905-1907 gg. », Cahiers du monde russe [En ligne], 48/2-3 | 2007, mis en ligne le 01 janvier 2007, consulté le 04 septembre 2022. URL : http://journals.openedition.org/monderusse/9005; DOI : https://doi.org/ 10.4000/monderusse.9005 
chercher : repérer : avancer

Cet article est disponible en ligne à l'adresse :

http://www.cairn.info/article.php?ID REVUE=CMR\&ID NUMPUBLIE=CMR 482\&ID ARTICLE=CMR 4820301

Partija socialistov-revoljucionerov vo vremja i posle revoljusii 1905-1907 gg

par Konstantin N. MOROZOV

Editions de I'EHESS | Cahiers du monde russe

2007/2-3 - Vol 48

ISSN 1252-6576 | ISBN 9782713221477 | pages 301 à 330

Pour citer cet article :

- N. MOROZOV K., Partija socialist ov-revoljucionerov vo vremja i posle revoljusii 1905-1907 gg, Cahiers du monde russe $2007 / 2-3$, Vol 48, p. 301-330.

Distribution électronique Cairn pour les Editions de l'EHESS.

(C) Editions de l'EHESS. Tous droits réservés pour tous pays.

La reproduction ou représentation de cet article, notamment par photocopie, n'est autorisée que dans les limites des conditions générales d'utilisation du site ou, le cas échéant, des conditions générales de la licence souscrite par votre établissement. Toute autre reproduction ou représentation, en tout ou partie, sous quelque forme et de quelque manière que ce soit, est interdite sauf accord préalable et écrit de l'éditeur, en dehors des cas prévus par la législation en vigueur en France. Il est précisé que son stockage dans une base de données est également interdit. 
КОНСТАНТИН Н. МОРОЗОВ

\title{
ПАРТИЯ СОЦИАЛИСТОВ-РЕВОЛЮЦИОНЕРОВ ВО ВРЕМЯ И ПОСЛЕ РЕВОЛЮЦИИ 1905-1907 ГГ.
}

\author{
Социокультурный феномен в контексте \\ субкультуры российского революционера
}

В современной литературе, можно встретить точку зрения, что о влиянии ПСР на крестьянское движение и в годы первой российской революции, и в годы гражданской войны 1918-1921 гг. говорить не приходится, или что, - в крайнем случае, - это влияние сводилось к минимуму: эсеры-крестьяне в ходе восстания становились во главе его, но ни на подготовку, ни на его начало (т.к. восстания вспыхивали стихийно) партия с.-р. влияния не оказывала ${ }^{1}$.

На наш взгляд нельзя смотреть на нелегальную российскую партию (и на эсеровские «крестьянские братства») сквозь призму старых историкопартийных представлений «о ведущей и направляющей роли» партии (которая сама есть нечто стройное, дисциплинированное, централизованное и легко управляемое из единого центра), дирижирующей всеми процессами по строго намеченному плану. Или как любили по этому поводу шутить противники такого восприятия партий в среде революционеров в начале $\mathrm{xx}$ века - «Die erste kolonne marschiert, die zweite kolonne marschiert, die dritte kolonne marschiert...». Споры между сторонниками и противниками такого взгляда на партию шли всегда, то затухая, то разгораясь вновь.

Представляется, что историк, ставший заложником мифов «Краткого курса истории ВКП(б)», не найдет не только влияния таких дисциплинированных

1. См.: В.В. Кондрашин «Партия эсеров и крестьянское движение в Поволжье в 1918

- 1921 гг.», Самарский край в контексте российской истории: Сб. ст., Самара, 2001, с. 121-132; В.В. Кондрашин Крестьянское движение в Поволжье в 1918-1922 г2., М.: "Янус -К", 2001. 
и централизованных партий, но и не найдет самих таких партий в России в революции 1905-1907 гг. (как впрочем и до и после нее), потому что их попросту не существовало в исторической реальности. Подобный подход игнорирует сам факт существования тысяч народных учителей, фельдшеров, агрономов, которые проникались эсеровскими идеями еще в учебных заведениях (эсеры были влиятельны даже в церковных семинариях) и которые, придя в село, вели пропаганду, а главное - приняли участие в создании тысяч и тысяч эсеровских «крестьянских братств». Примечательно замечание Н.В. Крыленко, выступавшего на процессе с.-р. в 1922 г. обвинителем и остроумно отмечавшего, что «эсеры все гнездятся либо по народному образованию, либо по кооперации» ${ }^{2}$.

А А.Р. Гоц в собственноручных показаниях 1937 г., которые алмаатинские чекисты переслали в Москву (позже в ЦА ФСБ РФ этот документ был приобщен к фонду процесса с.-p. 1922 г., под названием «Показания члена ЦБ террористической повстанческой орг. ПСР Гоц. ІІ том») $)^{3}$, оценивая кризис городских с.-р. организаций в 1917 г., констатировал, что «когда чрезвычайная популярность Керенского привлекла в ряды партии с.-р. огромные массы сочувствующих из кругов интеллигенции, мелкой буржуазии, кооперации, влила в партию с.-р. элементы социально разнородные, быстро разводнившие основные подпольные кадры партии, выкованные в период борьбы с царским правительством, и толкавшие партию вправо», «в деревне картина была иная...». Отчасти потому, что «классовая дифференциация в первый период революции еще не успела расслоить основную крестьянскую массу...», но в основном по иной причине: «Стремительный рост деревенских организаций не застал партию столь же не подготовленной, как в городе, в силу того, что партия c.-p. располагала довольно значительными кадрами деревенских работников.» ${ }^{4}$ Не случайно именно представители «народной интеллигенции» и крестьяне - вожаки эсеровских «братств» вставали во главе стихийно вспыхивающих восстаний (революционеров, считавших, что можно заставить крестьян или солдат подняться на восстание такого-то числа и в такое-то время по директиве ЦК ПСР, в эсеровской партии уже в годы революции 1905-1907 гг. становилось меньше и меньше, по мере того как на практике они понимали, что из себя в реальности представляют эти «партийные организации», каков механизм их бытования и функционирования $)^{5}$.

2. ЦА ФСБ РФ (Центральный архив Федеральной службы безопасности Российской Федерации), Н-1789, т. 12, л. 410.

3. ЦА ФСБ РФ, Н-1789, т. 95.

4. Там же, л. 2.

5. Один из таких «прозревших эсеров»- «крестьянский работник» в 1908 г. в одном из уездов Петербургской губернии констатировал: «судьба всех постановлений, принимаемых на съездах, конференциях, собраниях: они под сукном, самое большее если их прочтут». В то же время после революции 1905-1907 гг. оставшись без партийных руководителей и организаторов, многие рабочие и крестьянские эсеровские партийные организации пытались продолжать работу самостоятельно, а также обращаясь за помощью к еще работающим «партийным интеллигентам». Это явление было характерно прежде всего для рабочих организаций и групп Петербурга, Баку, целого ряда уральских 
Проблема взаимоотношения партии и масс все время рефлексировалась российскими революционерами и неоднократно становилась темой жарких споров «по проклятому» организационному вопросу, причем споры порой далеко выходили за рамки чисто организационных вопросов. Масла в огонь этого незатухающего спора (а также спора о том, что такое - партия и какой она должна быть в данных конкретных условиях) подлила революция 19051907 гг., дав многочисленные аргументы обеим спорящим сторонам.

Этот спор велся как в плоскости проблем организационного устройства партии и ее тактики, так в плане осмысления уроков революции 1905-1907гг.

То, что этот спор о взаимоотношениях партии и масс и извлечении уроков из революции 1905-1907 гг. не был схоластическим, а имел судьбоносное значение и не только для судеб ПСР, но и для страны в целом, становится ясным при чтении размышлений А.Р. Гоца об ошибках, допущенных руководством эсеров, не сумевшим извлечь правильных уроков из первой российской революции, в стихии следующей революции: «Мы - c.-p. и меньшевики - не поняли и не хотели понять, что октябрьская революция прозвучала для нас сигналом к уходу с командной вышки. < ..> С.-р. и меньшевики не поняли, что отрыв от народных масс в революцию не только равносилен политическому самоубийству для партии, и что еще хуже неизбежно приводит ее в силу логики борьбы в лагерь контрреволюции. Они утверждали, что не они отстали от двигавшихся вперед народных масс, а эти массы сами ушли в сторону от единственно правильного с.-p. - меньшевистского революционного пути. В такой оценке было много узкого доктринерства, политической высокомерности, барски-пренебрежительного чувства к массам, и всего менее было в нем подлинного народного демократизма.»6

Первая российская революция может по праву считаться своего рода «моментом истины» для молодых российских партий, впервые в ходе ее получивших возможность выйти из подполья и встретиться с массами, и также получить некоторые условия для относительно широкого партийного строительства. Однако не будем забывать, что эти условия можно назвать в лучшем случае полулегальными, вовсе не отменявшими систематических арестов революционеров и провалов партийных организаций. И тем не менее, несмотря на преследования и аресты все революционные партии стали массовыми. Но дело вовсе не сводится только к количественному росту партий - они стали иными, чем были до начала революции. Более того, применительно к ПСРможно с уверенностью утверждать, что в ходе революции 1905-1907 гг. ПСР пережила три разных качественных состояния.

заводов и городов, а также крестьянских организаций Полтавской, Харьковской, Курской, Тамбовской, Пензенской, Херсонской, Таврической и ряда других губерний. Подробнее о деятельности братств и крестьянских организаций см.: К.Н. Морозов Партия социалистов-революционеров в 1907-1914 г2., М., 1998, с. $29-54$.

6. ЦА ФСБ РФ, Н-1789, т. 95, л. 56-60. 
Но прежде чем говорить о состоянии ПСР в годы революции 1905-1907 гг., стоит обратиться к ключевому вопросу: а что есть партия вообее и российская партия в начале хх века, в частности?

Различные существующие определения политической партии весьма общи и не дают четкого ответа на интересующий нас вопрос: где проходит грань, отделяющая политическую партию от группы политических единомышленников, имеющих программу, устав, элементы организационной структуры и провозглашающих себя партией. Можем ли мы считать политической партией “Народную волю”, ПСР и РСДРП (до революции 19051907 гг.) и подавляющее большинство современных российских партий?

Как правило, при определении понятия политической партии помимо формальных признаков на первый план выдвигают обязательное наличие разветвленной организационной сети, охватывающей достаточно значительное число рядовых членов, плоть от плоти того класса или слоев, интересы которых собирается выражать партия. Кроме того, обращают внимание на наличие инструментария - партийная или околопартийная печать, партийные и беспартийные клубы, представительство в парламенте, профсоюзные, кооперативные и просветительские организации, находящиеся под влиянием данной партии. Но самым важным, вероятно, является реальная включенность представителей тех или иных слоев и классов в различные партийные структуры и подпадение под партийное влияние еще более широких слоев того или иного класса, групп, страт населения.

Подобное понимание политической партии весьма характерно для западных исследователей, берущих в качестве образца западноевропейские парламентские партии ХІХ-ХХ вв., что вполне логично, т.к. политическая партия это все-таки дитя западноевропейской цивилизации. Естественно, что, анализируя характер русских политических партий начала хx в., некоторые исследователи указывают на неполное соответствие их критериям и стандартам политической партии. Так, например, по мнению немецкого историка М. Хильдермайера, ПСР являлась чем-то средним между партией и социально-политическим движением ${ }^{7}$.

Пытаясь определить характер групп, из которых складывается в 19011902 гг. ПСР, М. Хильдермайер использует весьма удачный, на наш взгляд, термин «элитарно-конспиративных организаций». Как правило, это были небольшие группы единомышленников, зачастую связанных между собой дружескими отношениями. Лидерство в этих группах определял высокий личностный статус. Элитарность, замкнутость, конспиративность были абсолютно необходимыми свойствами, позволявшими им существовать (хоть какоето время) в условиях полного отсутствия легальности и полицейских преследований. Характер ПСР определялся, с одной стороны, родовыми чертами этих групп и полным отсутствием легальности в России (в силу этого партии были присущи ярко выраженные черты конспиративно-элитарной организа-

7. M. Hildermeier, Die Sozialrevolutionäre Partei Russlands. Agrarsozialismus und Modernisierung in Zarenreich (1900-1914), Köln-Wien, 1978, s. 32-33. 
ции); с другой стороны, в концепцию организационного строительства ПСР стремились заложить идеи и структуры массовой политической партии в соответствии с теми целями и задачами, которые ставила перед собой ПСР, чуть позже ставшая одной из партий II Интернационала. Эсеры, как и социалдемократы, будучи в здравом уме, не собирались строить массовую партию по организационной схеме СДПГ в российских условиях, но они, как уже отмечалось, рассматривали ее как образец, пример для подражания, возможный для претворения в жизнь лишь при достижении политических свобод, поэтому некоторые организационные и тактические принципы и черты подобной партии все-таки были использованы. Произошло, на наш взгляд, симбиотическое соединение черт традиционной «конспиративно-элитарной» организации и массовой политической партии. Подобный симбиоз можно охарактеризовать как эмбрион партии или протопартию. (В этом контексте примечателен ответ М.А. Натансона на вопрос ССК в 1910 г. о порядке приема в партию в начальный период ее существования: «Как принимались члены? Кого считали хорошим человеком, того и принимали.» ${ }^{8}$ Представляется, что многими своими чертами ПСР предреволюционного периода была похожа на «Народную волю», что отчасти объяснялось той огромной ролью, которую играли в руководстве ПСР этого времени видные деятели народнического и народовольческого этапов революционного движения. Вопреки широко распространенному взгляду на «Народную волю» как на организацию сугубо террористическую, она объединяла 80-90 местных, 100-120 рабочих, 30-40 студенческих, 20-25 гимназических и до полусотни военных кружков, имея в своих рядах до 500 активных юридически оформленных членов партии и в 10-20 раз больше участвовавших в той или иной степени в ее работе ${ }^{9}$. Эти параметры вполне сопоставимы, а в чем-то даже превосходят данные по ПСР и РСДРП накануне революции 1905-1907 гг.

Нам представляется, что с момента своего возникновения и до гибели ПСР пережила несколько состояний, которые носили достаточно выраженный характер со своими собственными чертами. Сугубо условно их можно обозначить так: протопартия (1902-1905 гг.), массовая нелегальная партия (19061909 гг.), атомизированная эсеровская среда с тенденциями к интеграции (1910-февраль 1917 г.), массовая легальная партия (март 1917-конец 1917 г.), а затем нелегальная массовая партия (1918-1921 гг.) и вновь эсеровская среда, существовавшая на свободе и в тюрьмах (вплоть до почти полного физического уничтожения эсеров $)^{10}$.

8. ГАРФ (Государственный архив Российской Федерации), ф. 1699, оп. 1, д. 123, л. 4.

9 См.: Н.А. Троицкий, «"Народная воля” и ее “красный террор”», Индивидуальный политический террор в России. хіх-начало ХХ в. Материаль конференции, M., 1996, с. 17.

10. О масштабах последнего отчасти можно судить по данным частичной проверки, проведенной МВД СССР весной 1949 г. контингента заключенных, подлежащих заключению в особых лагерях. Было проверено 83916 заключенных из 205728 , из которых 32 человека были эсерами $(0,03 \%), 44$ - меньшевиками $(0,05 \%), 99$ - «правыми» $(0,1 \%), 465$ - троцкистами $(0,5 \%), 17$ анархистами $(0,02 \%), 190$ - белоэмигрантами (0,3\%) (ГАРФ, ф. 9401, оп. 1, д. 3269, л. 56-59). 
До І съезда ПСР, состоявшегося в декабре 1905-январе 1906 г., партия эсеров не имела ни утвержденной программы, ни организационного устава, ни зафиксированного членства. Численность ее членов различные исследователи оценивают по-разному, но даже максимальные цифры не превышают 3 тыс. человек ${ }^{11}$. Активных членов ПСР, по словам Е.К. Брешко-Брешковской, насчитывалось «несколько сот молодых людей», а по оценкам М.И. Леонова в сфере партийного влияния эсеров находилось от полутора до двух тысяч человек при доминировании интеллигенции среди активных членов и в руководстве всех уровней ${ }^{12}$.

Вместе с тем существовал ЦК, который с помощью института уполномоченных пытался координировать деятельность достаточно широкой сети местных организаций, и центральная партийная печать, где рассматривались вопросы идеологии, тактики и партийного строительства. Немаловажно, что за границей и в России издавались газеты, брошюры и листовки, предназначенные для пропаганды в различных слоях общества.

Процесс превращения ПСР в массовую партию, более или менее соответствовавшую традиционным критериям таковой, начался в 1905 г. и достиг в следующем году своего апогея. На І съезде ПСР был принят организационный устав, определены критерии членства и более или менее разграничены полномочия всех партийных ячеек. Но нужно отметить, что этот процесс не был завершен и, как справедливо отмечал М.И. Леонов, ПСР организационно была «весьма рыхлой, с дисциплиной не из строгих, сплоченностью не из крепких» ${ }^{13}$.

С осени 1906 г. ПСР быстро росла вширь, ЦК едва успевал организационно закреплять стихийно возникающие партийные группы и комитеты. Крайне характерно, что даже в этот период, ПСР с большим трудом координировала деятельность отдельных своих комитетов. Порой даже губернские комитеты не имели в течение нескольких месяцев связи с ЦК, который в свою очередь не получал информацию от многих губернских, городских и даже областных комитетов, не говоря уже об уездных группах.

Таким образом, хотя ПСР удалось стать массовой партией, объединявшей в сотнях своих организаций около 60-65 тысяч членов, и охватить партийным влиянием около трехсот тысяч человек, а также иметь собственную фракцию во II Государственной Думе и многочисленные легальные и нелегальные издания, руководство партии сталкивалось с огромными организационными сложностями.

Уже с конца 1908-середины 1909 г. ПСР теряет качества массовой политической партии. Таким образом, можно констатировать, что за годы революции 1905-1907 гг. ПСР прошла через три качественно отличных

11. Н.Д. Ерофеев, «К вопросу о численности и составе партии эсеров накануне первой российской революции» в Непролетарские партии России в трех револющиях, М., 1989, c. 127.

12. См.: М.И. Леонов, Эсеры в революции 1905-1907 г2., Самара, 1992, с. 15.

13. Там же, с. 8. 
состояния, когда по самым разным параметрам она не была тождественна самой себе. Вступив в нее в январе 1905 г. типичной конспиративноэлитарной организацией, хотя и имевшей ряд рабочих, солдатских кружков и крестьянских братств и амбиции быть массовой партией, таковой ПСР становится только уже в разгар революции, когда, начиная с конца 1905 начала 1906 г., происходит взрывоподобный рост ее рядов и ее организацией. В конце революции 1905-1907 гг. партия с.-р. начинает переходить в третье состояние, черты которого становятся все более и более явными после поражения революции.

С одной стороны, численность ее членов все более и более приближается к предреволюционной, а ее структура ослабевает, теряя соединительные звенья (обкомы и губкомы). С другой стороны, партия теряет инструменты воздействия на массы и перестает оказывать сколько-нибудь заметное влияние на политическую жизнь страны. Совершенно не случайно, что на одно из первых мест лидеры партии пытаются в это время выдвинуть центральный террор, имевший в предреволюционный период огромное значение для роста авторитета и влияния партии. Но в силу ряда причин и это оружие оказалось малопригодным, как и попытки военных восстаний, имевших своей целью поднять всенародное вооруженное восстание.

Не смогла ПСР вернуть и предреволюционное свое качество. Дело в том, что цементирующими началами предреволюционной ПСР, как и всех подобных ей конспиративных организаций (начиная с «Народной Воли»), являвшихся «организациями единомышленников», служили идейные мотивы, особый этический кодекс, зачастую личное знакомство и дружба большинства партийных деятелей. Революция и годы «реакции» практически разрушили этот комплекс «внутреннего единства и братства»: с одной стороны, став массовой партией, ПСР подверглась нашествию новых элементов, вносивших в партийную жизнь много такого, что кардинально противоречило этике профессиональных революционеров, составлявших ранее костяк партии. С другой стороны, в партии установились отношения, характерные именно для массовой партии: централизация, подчинение нижестоящего вышестоящему не в силу авторитета последнего, а в силу партийной дисциплины, что вызывало недовольство «бюрократизацией партии».

Можно сказать, что ПСР, как и другие российские революционные партии (да и не только они) оказалась не готова к экзамену первой российской революции. Прежде всего, не оправдались некоторые имевшие место у многих революционеров иллюзии. Революция 1905-1907 гг. показала не только силу массового движения рабочих, крестьян, солдат и матросов, но и его слабость, стихийность и разрозненность. Кроме того, революция показала, что, с одной стороны, партии бурно росли и развивались, радуя глаз партийных руководителей, а с другой, вобрав в себя массу людей, чуждых субкультуре революционера, партии стали испытывать огромное количество самых различных проблем, в том числе и таких, которых совсем не ожидали. 
Ведь в годы первой российской революции революционная интеллигенция столкнулась не только со зверствами черносотенцев, жестокостью правительственных карательных отрядов и «скорострельных» военно-полевых судов - к этому морально она была подготовлена. Она столкнулась с тем, чего никак не ожидала увидеть: террористические акты революционеров, в ходе которых гибли невинные люди, половодье экспроприаций, принимавших порою формы откровенной уголовщины, расцвет полицейской провокации, заполонившей ряды оппозиционных партий, приход в революционные партии откровенно люмпенизированных и «ушкуйнических» элементов и многое, многое другое, что никак не вписывалось в двухполюсные, черно-белые представления интеллигенции о революции.

Представляется, что слова А.Р. Гоца о революции 1917 г. вполне применимы и к первой российской революции:

Конечно, все мы из истории знали [писал он в 1937 г.], что революция пахнет потом и пороховым дымом, что она прекрасна в своих героических порывах, но и беспощадна в своей мстительности к врагам, что она полна энтузиазма и самопожертвования, но часто бывает омрачена преступлениями, которые творятся во имя ее подонками народных низов, что в ней наряду с самыми возвышенными чертами проступает и изнанка человеческой натуры. Все это мы - повторяю - знали из истории, и все это мы принимали. Но когда революция явилась перед нами в своем реальном обличии, психологически несколько попятились от нее. Из-за деревьев мы перестали видеть лес, из-за отдельных уродливых, случайных, наносных черт мы не увидели суровое, но прекрасное лицо революции. Когда начались пьяные бунты в Петрограде, разгромы художественных ценностей в частных квартирах, стрельба по памятникам искусства, убийство Кокошкина и Шингарева и т.п. явления, мы склонны были переоценивать их политической значение, не отдавая себе отчета в том, что бурный стремительный разлив многоводной реки всегда поднимает со дна муть и грязные обломки, что в бурю листья всегда ведь поворачиваются изнанкой. ${ }^{14}$

Наплыв в партию случайных людей имел очень серьезные и различные последствия. Видный энес А.В. Пешехонов, вспоминая о спорах будущих энесов и эсеров на І съезде партии ПСР, много лет спустя справедливо отмечал: «Мы находили, что конспиративной может быть лишь небольшая организация, состоящая из людей, хорошо знающих друг друга, и во всяком случае из людей, моральная чистота которых стоит вне сомнения. Когда же число членов партии начинает быстро увеличиваться, а в таком именно положении и находилась партия с.-р., то оставаться ей в подполье, где нет гласности и где контроль до крайности затруднен, прямо опасно. В партию легко могут проникнуть элементы, далеко не безупречные в моральном и политическом отношении, и избавиться ей от них будет очень трудно. Наши опасения на этот счет оправдались - оправдались даже в гораздо большей степени, чем мы боялись.» 15

14. ЦА ФСБ РФ, Н-1789, т. 95, л. 60.

15. А.В. Пешехонов, Почему мы тогда ушли (К вопросу о политических группировках в народничестве), Пг., 1918, с. 7. 
В марте 1908 г. один из казанских эсеров писал в столицу своему приятелю: «Я убедился в том, что даже и $3 \%$ истинных деятелей нет. Как я верил слепо в силу и правоту, бескорыстность и искренность партии с.-р. Но когда я стал вращаться в их среде, познакомился поближе, то горько разочаровался... Сколько там есть лиц, совершенно не знакомых даже с программой или понимающих ее совершенно превратно, затем большинство “горячих" и “фанатичных" с.-р. (какими они кажутся перед толпой) на самом деле люди совсем даже не убежденные.» ${ }^{16}$

Но настоящим бичом для эсеров в революционные и пореволюционные годы стало повсеместное увлечение экспроприациями и т.н. «революционное хулиганство. Важно иметь в виду, что в отличие от БО ПСР и центральных боевых отрядов отбор в местные боевые дружины осуществлялся не с такой тщательностью. Этим не в последнюю очередь объясняется та вакханалия экспроприаций, которая охватила местные организации уже с конца 1906 г. и усилилась в последующие годы. Порой «экспроприаторская лихорадка» принимала формы полууголовщины и не только наносила огромный вред авторитету ПСР, но и вела к разложению боевых дружин, да и партийных организаций в целом.

Севастопольский эсер С.А. Никонов вспоминал, как после успешной экспроприации в почтово-телеграфной конторе, проведенной севастопольской боевой дружиной летом 1906 г., к нему, жившему легально и поэтому скрывавшему свою связь с местной эсеровской организацией, пришел рабочий морского завода, заявивший, что он работает в организации, помогает боевой дружине. Он просил выдать ему из экспропрированных денег пособие в размере 400 или 500 рублей на покупку коровы, ремонт домика и другие хозяйственные дела. Никонов ответил ему, что никакого отношения к комитету не имеет и что вообще революционные организации не занимаются благотворительностью и не помогают тем своим членам, у которых есть домик и заработок. Через несколько дней этот посетитель вновь пришел к Никонову и требовал от него «хоть 200 рублей», так что пришлось его буквально выгонять из квартиры. Наведя справки об этом человеке, Никонов узнал, что это «один из периферических членов организации, действительно оказывавший кое-какие мелкие услуги и знакомый кое с кем из боевиков». «До меня доходили впоследствии слухи, - вспоминал Никонов, - что он вскоре связался с какими-то анархо-бандитскими группами, уехал на родину, где принимал участие в налетах, и в конце концов попался и был осужден на каторгу.» ${ }^{17}$

По мнению С.А. Никонова, подобные процессы были обусловлены «кроме прямого фактического уничтожения членов революционных организаций» также «деморализующим влиянием провокации, широко, как никогда на протяжении нашей истории, практиковавшейся именно в эти годы ликвидации революции 1905 года. И, наконец, в партиях с.-р., с.-р. максималистов и

16. ГАРФ, ф. 102, ДП ОО, 1908, д. 9, ч. 18, л. 100.

17. РГАЛИ (Российский государственный архив литературы и исскуство), ф. 1337, оп. 1, д. 161 л. $165-166$. 
анархистов, признававших идовольношироко практиковавших экспроприации, прибавлялось развращающее влияние этого рода выступлений.» ${ }^{18}$

Увлечение «эксами» вызывало серьезную тревогу у части революционеров «старого закала», пытавшихся (подобно лидерам ПСР Брешко-Брешковской, Гершуни, Чернову и др.) отсечь «экспроприаторскую язву» или хотя бы предотвратить самые гнусные эксцессы экспроприаторства.

Так, на II съезде ПСР в феврале 1907 г. руководство партии предприняло попытки ликвидировать «экспроприаторскую гангрену» и взять проведение экспроприаций под жесткий контроль ЦК. Но даже пламенные речи Е.К. Брешко-Брешковской, Г.А. Гершуни и В.М. Чернова с большим трудом переломили настроение большинства делегатов не ограничивать их прав на проведение экспроприаций.

После поражения революции 1905-1907 гг. вновь вспыхнули старые споры о принципах партийного строительства. Парадоксальным образом первая российская революция дала аргументы как сторонникам массового движения, делавшим ставку на всенародное вооруженное выступление и революции, скептически относившимся к террору, так и сторонникам террористической тактики, увидевшим к концу революции именно в терроре единственное средство для свержения царизма. Последние подвергли жесткой критике руководство эсеровской партии, взявшей в качестве образца для партийного строительства немецкую социал-демократическую партию. Так, один из сторонников группы «инициативного меньшинства» и авторов «Революционной мысли», указывая в 1908 г., что в основе организационных концепций большинства российских партий лежит концепция германской с.-д. партии, действовавшей в легальных условиях, констатировал, что соединить задачу организации различных слоев общества на демократических основаниях и необходимость действовать подпольно - весьма сложно. Эсеры, по мнению автора, поставив цель строительства “массовой” партии по западноевропейскому образцу, взвалили на себя невыполнимую задачу. Ведь помимо организации пролетариата, партия эсеров берет на себя задачу и организации крестьянства и подготовку его к всеобщему вооруженному восстанию, и кроме того еще и ведение террористической борьбы. Кроме того, наличие партий вело, наряду с внутрипартийной, к острой межпартийной борьбе, ослаблявшей силу революционного натиска на царизм. Симптоматично, по мнению автора, и противоречие между отношением низовых членов разных партий к объединению и раздуванием партийного фанатизма верхами этих партий. Нелегальные условия вели к авторитарности руководства партии, сосредоточивавшего в своих руках все нити, средства и силы ее. Более того, в годы революции ЦК партии эсеров был просто завален работой, его разрывали на части ходоки с мест, ждавшие приема неделями. Автор статьи показывал, что будучи не в состоянии выполнить задачи управления и руководства партией, находящейся в подполье, концепция массовой партии к тому же таит в себе множество грехов и минусов. Это и самодовлеющий характер корпоративных интересов партии,

18. Там же, л. 212-213, 220. 
система централизма, ведущая к исчезновению товарищества и доверия, заменяющая их дисциплиной и подчинением. Это и борьба за влияние и власть в партии, умение приспособиться к требованиям партийной дисциплины и политики, умение лавировать среди различных влияний в партии и т.п. Для того чтобы примирить противоречие между практикой и партийной моралью, создается целая искусственная система, где административный централизм, кооптацию и личную инициативу пытаются примирить с выборным началом и проведением партийных съездов, и где первые в силу невозможности организации демократических выборов и контроля всегда торжествуют ${ }^{19}$.

Как видим, диагноз «массовой нелегальной партии» ставился достаточно серьезный. В другой статье его единомышленник от диагноза переходил к способам лечения болезни - предлагал децентрализовать всю партийную организацию. По его мысли, необходимы партийные ячейки, ведущие пропаганду среди рабочих, крестьян и особенно среди войск, но не управляемые из одного заграничного центра, что, с одной стороны, и невозможно, а, с другой - только стесняет их и угрожает их безопасности. Объединение этих автономных групп должно произойти на общих принципах программы и тактики, вокруг тех 2-3-х печатных органов эсеровской мысли, которые им ближе по духу, на местных съездах и конференциях. Если какие-либо организации не сойдутся в частностях, это все-таки лучше, чем сглаживать противоречия путем никого не удовлетворяющего компромисса ${ }^{20}$.

Усиливается критика в адрес руководства партии и со стороны “правых", группировавшихся вокруг «Известий ОЗК». Вслед за Л.М. Арманд (Л.А-ва), в «Знамени труда» выступил Н.Н. Соколов («Старый работник»), в довольно резких выражениях упрекнувший редакцию ЦО за нежелание разбираться в новых вопросах, поставленных жизнью. По его мнению, не только азефщина и организационный развал партии приводят к оттоку партийных кадров, но и их сомнения «в старых приемах и путях работы» ${ }^{21}$. Он категорически требовал прекратить экспроприации, деморализующие партию и покрывающие ее позором, т.к. партия должна существовать не «на подачки и деньги с эксов», а на взносы ее членов и материальную поддержку народа. Но основной пафос статьи был направлен на критику игнорирования руководством партии разработки насущных вопросов профсоюзного, кооперативного, рабочего движения и глубинных процессов, которые происходили в русской деревне ${ }^{22}$. «Правые» резонно говорили, что для пропаганды в массах достаточно групп и даже одиночек-пропагандистов.

Особо жаркие споры разгорелись в революционной среде после того, как болезненную проблему осмысления революции и места в ней интеллигенции

19. Одинцов, «К вопросу о революционных организациях (Письмо в редакцию)», Революционная Мысль, 1908, № 2, с. 10-12.

20. «О децентрализации», Революционная Мыслль, 1909, № 4, с. 3-4.

21. Старый работник, «Наболевшие вопросы (Письмо к товарищам) », Знамя труда, 1910, № 25, c. 10 .

22. Там же, с. 11-13. 
(и партий) затронул в 1912 г. Б.В. Савинков (В. Ропшин) в своем романе «То, чего не было (Три брата)».

Апеллируя к многочисленным примерам первой российской революции, Б.В. Савинков указывал на стихийность большинства ее процессов и считал саму возможность управления народными массами самообманом партийных работников. Представляется, что возмущение его критиков было бы значительно больше, если бы Савинков опубликовал не смягченный, а первоначальный вариант одной из важных сцен романа, дошедший до нас в рукописном черновике. Вот как выглядит там сцена обсуждения партийными руководителя вопроса о восстании в одном из полков после выступления представителя военной организации этого полка «товарища Давида»:

Они говорили в уверенности, что от их разговора зависит судьба двух тысяч солдат, что две тысячи человек по их первому слову пожертвуют самым ценным, что у них есть, - жизнью, и начнут убивать людей. Они забывали о том, что если люди решаются на убийство, на бунт и на смерть, то конечно не потому, что пятеро неизвестных считают это хорошим, полезным и нужным, и что решение этих людей зависит от неисчислимого множества непредвиденных и случайных причин. Так, восстание может вспыхнуть внезапно, оттого, что к обеду подадут несвежие щи, и наоборот, полк легко успокоится, если начальство вовремя сменит вора ротного командира или арестует наиболее бойкого из солдат. Главное же, они забывали о том, что никто над чужой жизнью не властен и что люди в минуту смертельной опасности руководятся не запрещениями и приказами, и даже не чувством долга, а своим кровными, обнаженными интересами. <...> Ни Арсению Ивановичу, ни Вере Александровне, ни Болотову, ни доктору Бергу и в голову не пришло усумниться в словах Давида. Им опять казалось естественным и законным, что в какие-нибудь полгода, деревенские, взятые от сохи, парни превратились волшебством из послушных и скованных дисциплиной солдат в самоотверженных и готовых к мятежу революционеров. Давид искренне верил в свои слова, и они искренне верили Давиду. Они не могли не верить ему: он говорил как раз то, что им хотелось услышать. ${ }^{23}$

В адрес Б.В. Ропшина часто раздавались со стороны его критиков обвинения в неточности и упрощенности описания революционных событий, но в данном случае следует сказать, что описание восстания в полку Давида - это точное и яркое описание неудачной попытки в ночь с 14-го на 15-е сентября 1907 г. поднять Брестский полк в Севастополе, сделанное Б.В. Савинковым со слов участников Севастопольского восстания. Достаточно сравнить тексты романа Б.В. Савинкова и одного из участников восстания офицера Максимова, опубликованного в «Былом» в 1917 г., чтобы убедиться в этом ${ }^{24}$.

Болезненная реакция революционеров на попытки Б.В. Савинкова поновому взглянуть на революцию 1905-1907 гг. и на самих революционеров,

23. ГОПБ (Государственная общественно-политическая библиотека), ОРК (Отдел редкой книги), черновик романа Б.В. Савинкова, «То, чего не было. Три брата», тетрадь I, л. 5-6. Сравни: Б.В. Савинков То, чего не было. Роман, повести, рассказы, очерки, стихотворения, М.: «Современник», с. 221.

24. Максимов, «Попытка восстания в Севастополе в ночь с 14 на 15 сентября 1907 г. », Бbилое, 1917, № 3(25), с. 17-32. 
предпринятые им в повести «Конь Бледный» и в романе «То, чего не было» объяснялась также еще и тем обстоятельством, что в конце революции 1905-1907 гг. и в пореволюционный период разочарование в революции, революционерах, в политической и общественной деятельности становится массовым, доминантным явлением, приметой времени. Оппозиционные партии оказались вдруг в изоляции, без окутывавшего их и ставшего уже привычным ореола борцов за народное дело и справедливость, а отшатнувшаяся от них интеллигенция принялась осмысливать происшедшее, а то и просто «уходить в личную жизнь». Знамением времени стали ее равнодушие к общественным вопросам, поворот от рационализма к мистицизму, от материализма к идеализму, расцвет символизма, поиск нетрадиционных путей решения стоящих перед русским обществом вопросов. Плоть от плоти, кровь от крови интеллигенции - все оппозиционные партии, черпавшие в ней свои кадры, финансовую и моральную поддержку и постоянно к ней апеллировавшие, крайне болезненно переживали ее «уход в себя».

Бывший народоволец К.Р. Кочаровский, анализируя причины того, почему эсеры не смогли «слиться» с народом и одержать победу над чужеродными для русского народа идеями социал-демократии, писал:

Социалисты-революционеры в пять лет - 1902-1906 гг. - одержали огромные победы - завоевали почти все крестьянство (в лице “сознательных” элементов), половину революционной интеллигенции, заметную часть пролетариата (в Петрограде - половину), но не разбили социал-демократию окончательно. И не могли этого сделать по причине сколь простой, столь же глубокой: они не противопоставили их доктрине свою доктрину. Они побеждали просто силой отдельных личностей в их рядах - бесчисленны и блестящи победы такого духа, как Брешковская, такого таланта, как Чернов. Они побеждали неотразимым обаянием своей героической боевой тактики: их террористы быть может выдержат сравнение даже с народовольцами, их кровь сияла народу ярче всех красных знамен и прокламаций. Они побеждали своей аграрной программой, в которой наиболее созрело народническое учение и которая законченно выразила интересы и правосознание крестьянского народа России. Но это все были отдельные частные пункты: это были отдельные люди, это был отдельный пусть решающий пункт программы, но это не было некоторое связное целое, это не было новое учение народничества, восстающее и всепобеждающее как цельная цель, как интегральная социальная религия. А только это могло дать полную победу народничеству, ибо именно этого ждал и жаждал русский народ, - и ждет и жаждет каждый народ в мире от социализма. ${ }^{25}$

Эсерам в некоторых случаях удалось найти удачные формулы выражения своего революционно-социалистического миросозерцания и задач, которые они перед собой ставили, легко воспринимаемые русским народом, такие, как, например, «Земля и воля», «Черный передел», «Народоправство». Другими словами, они «перевели на русский», «русифицировали» такие важные элементы социалистической теории, как «социализация собственности» (в данном случае помещичьей, церковной и удельной земли) и «политической свободы». Можно долго спорить о том, насколько адекватен был такой «пере- 
вод». В частности, понятие «политические свободы» вряд ли вполне адекватно расплывчатому понятию «воли». Но с другой стороны, трудно согласиться с весьма традиционным взглядом, что неизбывная мечта русского народа о «воле-волюшке», прекрасно отраженная в его сказаниях и песнях, это мечта лишь о вседозволенности и анархии. Может быть, трагедия русского народа отчасти заключалась и в том, что он был по разным причинам веками ограничен в возможности создания таких форм политической демократии, которые явились бы надстройкой и продолжением низовой, общинной демократии, доказавшей способность служить базой для более сложных форм политической демократии типа Новгородской и Псковской вечевых республик, насильственно ликвидированных более авторитарным московским режимом.

Но ни эсеры, ни другие социалисты не смогли дать формул, в которых переплеталась бы морально-нравственная мотивация революционной борьбы, а также социального переустройства общества и «народное православие». Необходимость поисков подобной «интегральной социальной религии» ощущала та часть интеллигенции, которая видела, что атеистическое социалистическое мировоззрение не дает ответа на ряд важных мировоззренческих вопросов. Подобные сомнения привели к отходу от марксизма таких видных его адептов, как Н.А. Бердяев и С.Н. Булгаков. Ограниченность диалектического материализма понимали и ощущали и видные социал-демократы - А.А. Богданов, обратившийся к эмпириокритицизму, и А.В. Луначарский, дошедший в своих поисках до богостроительства.

Подобная попытка на эсеровской почве была предпринята Д.С. Мережковским и 3.Н. Гиппиус, пытавшимися создать своеобразную религиозно-революционную организацию в форме «ордена» при ПСР, при помощи и поддержке И.И. Фондаминского и Б.В. Савинкова, с которыми у них сложились весьма дружественные отношения. Кроме того Гиппиу выступила в роли своеобразного литературного консультанта и учителя, когда Б.В. Савинков принес им первые куски своих воспоминаний ${ }^{26}$, а затем и «Коня бледного» ${ }^{27}$.

Значение, которое Д.С. Мережковский и З.Н. Гиппиус придавали «Коню Бледному», передают строки З.Н. Гиппиус из ее письма М.С. Шагинян в янваpe 1911 г.: «...этого “Коня”, несовершенного, но бесконечно важного и тогда нового, важного бытием своим, - мы родили жеребеночком, холили и кормили чуть не своим мясом, во всяком случае здоровьем» ${ }^{28}$.

Оценивая повесть «Конь Бледный», Д.С. Мережковский писал Б.В. Савинкову: «Имейте в виду, что романа печатать в России невозможно. А между тем печатать его нужно. Вещь очень серьезная - и надо, чтобы революционеры ее прочли. Она очень подействует. И благотворно. Заставит думать.» ${ }^{29} \mathrm{~B}$ последнем предсказании Д.С. Мережковский серьезно ошибся.

26. 3.Н. Гиппиус, Дмитрий Мережковский, с. 422-423.

27. Там же, с. 425-426.

28. М.С. Шагинян, Человек и время: История человеческого становления, М., 1982, c. 343.

29. ГАРФ, ф. 5831, оп. 1, д. 27, л. 3-4. 
Именно неадекватное отражение событий революции 1905-1907 гг. и неверное отображение роли революционных партий в них, а также «богоискательство» в «Коне Бледном» и «То, чего не было» - и стало главным обвинением в адрес Б.В. Савинкова.

В предисловии к повести, которое Б.В. Савинков написал в 1924 г., он вспоминал:

«Конь Бледный» был встречен с недоумением. Мне приписали разочарование в терроре, что было неверно. В Жорже увидели меня самого, в Ване, Генрихе, Федоре, Эрне - погибших членов Боевой Организации. Повесть возбудила споры, - за и против террора. Я оказался на дурном счету у ЦК ПСР. <...> Разумеется, «Конь Бледный» не автобиография, Жорж - не я, и остальные герои повести - не портреты. Таких террористов не было. Но в Боевой Организации, естественно, не раз возникал вопрос о терроре, - вставала та огромной важности проблема, которую разные люди решают различно, но над которой не задуматься невозможно. Я говорю о проблеме насилия. Допустимо насилие или нет? Допустимо убийство или нет ? Я не пытался эту проблему решить. Я хотел ее только поставить. Мне казалось, что ей уделяется слишком мало внимания. «Быт» же Боевой Организации явился не более, как предлогом для постановки этой проблемы. Это понял Е.С. Сазонов, который из Акатуйской тюрьмы протестовал против готовившегося уже тогда моего отлучения от эсеровской церкви. ${ }^{30}$

На Б.В. Савинкова, попытавшего иначе взглянуть на революционные события 1905-1907 гг., обрушился вал недовольства и раздражения, как это видно из откликов на роман его сопартийцев. Так, В.М. Чернову переслали выписку из двух писем «бабушки русской революции» Е.К. Брешко-Брешковской, написанных ею летом 1912 г., где она отмечала:

Что же касается «беллетриста» Р/опшина/, то пора бы ему перейти в журнал, где любят пугать людей, и молодежь в особенности, разными буками, людоедами и гипнотизерами. Я не читала его первого произведения, столь удивившего свет, но сие прочла по настоянию близких и впечатление такое, как будто имела перед собою карикатуру лубочного рисунка. Точно картонные фигурки, которые ниткой дергаются. <...> Или это они сами себя изображают? Так зачем всех в одно лукошко сажают??!

В другом своем письме от 31 августа «бабушка» восклицала: «Ропшина не могу читать: тошно!» ${ }^{31}$

В.И. Сухомлин писал В.М. Чернову о своем отношении к роману Б.В. Савинкова:

$<\ldots>$ в романе поражает, по-моему, отсутствие перспективы, отсутствие, так сказать, воздуха на его полотнах: нужные для Ропшина лица как-то все расположены на одном плане, на одной плоскости; вокруг них и за ними (м.б., главным образом, в них самих) нет ничего, что давало сколько-нибудь яркое представление о громадном народном возбуждении, о широком общественном движении, в атмосфере которого жила и частью которого была революцион-

30. Там же, л. 22-23.

31. ГАРФ, ф. 5847, оп. 1, д. 97, л. 75-76. 
ная партия. [...] «Эпоса русской революции», о котором говорили, никакого не получилось $<\ldots .$. . $^{32}$

Б. Черненков писал В.М. Чернову:

Чувствуется, когда читаешь «То, чего не было» «надрыв» в душе В. Ропшина. Право, можно подумать, что главная идея автора - доказательство аморализма всякой революции, полная стихийность всякого народного движения и оторванность «массы» от «вождей». <..> Много несправедливого чувствуется в романе, когда автор описывает Декабрьские дни. Пусть ни я, ни большинство в Москве не были, но ведь в конце концов герои Р/опшина/ превращаются в каких-то «мастеров красного цеха», которыми руководит одна ненависть и профессия. Характерно, что это выражение из «Коня Бледного» вошло в обиход редакционной печати («Новое время» и др.). ${ }^{33}$

И.И. Фондаминский писал Б.В. Савинкову в ноябре 1912 г.:

По некоторым фразам в Ваших письмах я начинаю думать, что Вы снова себя чувствуете травимым и Вам непонятно почему ваши друзья за Вас не заступаются. Но поймите, что это слабость с Вашей стороны. Разве Вы могли ожидать другого отношения к вашему роману $<\ldots>$ K нападкам же на Ваш роман Вы должны относиться спокойно и мужественно. Нападение сделали не «они», а Вы, они только защищаются. ${ }^{34}$

На наш взгляд, причины того, с чем столкнулась ПСР в годы революции 1905-1907 гг. - наплывы в партию случайных людей, «революционное хулиганство», низкая дисциплина и сознательность (после революции слово «сознательный» в устах питерских рабочих приобретает уничижительноругательный смысл, т.к. многие профсоюзные и партийные функционеры из рабочих были уличены в растратах и воровстве ${ }^{35}$ ), нужно искать прежде всего в общих социально-психологических и политических условиях России того времени. Низкий уровень политической культуры основной массы населения, внезапно «проснувшегося» и «открывшегося» для политики и партий, делал эту массу не самым пригодным материалом для организационного строительства партий. Подобная внезапность перехода к политике и партиям, в отличие от постепенного, медленного втягивания немецких рабочих в СДПГ, никак не способствовала формированию ни партийной дисциплины и политической сознательности, ни строительству крепкой организации, основу которой составляли бы самодеятельные партийные ячейки. Результат формирования массовой организации из столь «сырого» и неподходящего материала мог быть только один: невысокий уровень политического сознания ее членов, низкая дисциплина, катастрофическая нехватка навыков самоуправления и

32. Там же, л. 875.

33. Там же, л. 1010-1011 об.

34. ГАРФ, ф. 5831, оп. 1, д. 208, л. 87-88.

35. См., например, выступление питерского делегата на V Совете партии в мае 1909 г.: «Несколько довольно дельных и развитых рабочих с.-р., которые как представители социалистов-революционеров выступали в профессиональных союзах, проворовались. [...] Затем в партийной организации был такой случай: кассир Александро-Невского района присвоил себе деньги» (Международный институт социальной истории, Архив ПСР, 146). 
умелых партийных организаторов, слабость всех горизонталей и вертикалей организационной структуры и т.п. В этой связи многие проблемы и пороки эсеровской организации можно смело распространить на все российские оппозиционные партии.

Главной фигурой «конспиративно-элитарных организаций» и «протопартий» был «профессиональный революционер», вербовавшийся, как правило, из интеллигенции. Такие черты, как низкая исполнительская дисциплина, пропасть между партийнымцентромипериферией, невозможность самофинансирования местных организаций (в том числе из-за нежелания их членов платить взносы), зависимость от финансовой и кадровой помощи центра, напряженные отношения между местными руководителями комитетов и партийной массой - все это было характерно для многих российских партий. Но иначе и быть не могло. Даже правые и либеральные партии, находившиеся в несравнимо более благоприятных условиях, чем ПСР или РСДРП, испытывали серьезные организационные трудности и в годы революции, и после нее.

Конспиративная жизнь диктовала и такие вещи, как привычка к расхождению между словами о внутрипартийной демократии и реальной практикой, где процветали кооптации, конспирирования друг от друга и недемократичность партийных комитетов. Последняя вообе стала притчей во языцех. Говоря о предреволюционном периоде, И.А. Рубанович в 1910 г. отмечал:

$<\ldots>$ я тогда смотрел так, что вообще в партии совершенно не выяснены были организационные и функциональные отношения: Кто такой Центральный Комитет? Кто такие эти заправилы официальными органами? и почему они являются заправилами? ${ }^{36}$

Вспоминая І съезд партии на рубеже 1905-1906гг., Рубанович восклицал:

$<$...> вот начинаются выборы в Центральный Комитет, по рукам циркулирует неизвестно кем составленный список кандидатов, и во время выборов все, как бараны, подают свои голоса за этих пять намеченных человек. ${ }^{37}$

В то же время в эсеровской среде всегда были широко представлены стремления к созданию организаций на принципах демократии и федеративности. Они опирались на миросозерцание и идейные взгляды людей, смотревших на себя как на социалистов и демократов. Кроме того, они были укоренены в обычном праве конспиративно-элитарных кружков, члены которых, как правило, были связаны личными, а подчас и дружескими отношениями. Даже при объединении в рамках единой партии эти кружки или организации оставались во многом самодостаточными, строя свои взаимоотношения с центром и другими организациями на федеративных началах. Организации даже низового уровня принимали свои собственные уставы, а в работе опирались, как правило, только на свои собственные силы. Связь и помощь со стороны центра партии носили нерегулярный и недостаточный характер.

Для предреволюционного периода существования ПСР характерны странное переплетение формально не очерченных принципов и форм федеративно-

36. ГАРФ, ф. 1699 , оп. 1, д. 129 , л. 61.

37. ГАРФ, ф. 1699 , оп. 1, д. 129, л. 67-68. 
го и централистического устройства. Само создание партии носило характер федеративного договора представителей различных организаций. Но руководящий центр составлялся достаточно стихийно, даже случайно, не имел четко очерченных полномочий и четких механизмов их организационной реализации.

Несомненно, центр пытался регламентировать партийную жизнь, стремился к созданию властной вертикали, к централизации партии. Но так же несомненно, что эти попытки очень серьезно сдерживались и неизжитым обычным правом, которое приходилось учитывать членам ЦК, и слабостью самого центра, и отсутствием необходимых возможностей, сил и средств для превращения малочисленных, почти автономных, глубоко законспирированных организаций в централизованную, дисциплинированную партию. Да и сама степень приверженности идеям централизации у эсеровского руководства была в целом неизмеримо слабее, чем, скажем, у большевиков и Ленина.

Эсерам был чужд идеал «ордена меченосцев», они, скорее, ориентировались на эталонную партию II Интернационала - СДПГ, - конечно, с учетом суровой российской специфики. Неслучайно, что у эсеров не было единого лидера-вождя харизматического типа, а существовала группа таких лидеров из 4-5 человек, которых можно обозначить как своеобразного «коллективного лидера». Применительно к отдельным членам эсеровского руководства мы, пожалуй, можем говорить о стремлении к централизации, строительству сверху и т.п. Но говорить об этом можно лишь с учетом, с одной стороны, природы и психологии любого руководящего центра, силою вещей стремящегося усилить свою власть и расширить свои полномочия; с другой стороны, с учетом нелегальных условий России, из которых вытекала невозможность существования открытой, с демократическими, гласными процедурами и системой взаимного контроля организации.

Но помимо привычного обращения к организационной составляющей партийной конструкции, следует сказать о том, что традиционно ускользает из поля зрения историков, о том, что являлось, так сказать, душой «конспиративно-элитарной организации» - о субкультуре российского революционера, которая всерьез повлияла и на само становление российских партий, и без понимания которой мы не в состоянии адекватно оценить многое в истории российского революционного движения и взаимоотношениях российских революционных партий.

Революционеры-мемуаристы, пытаясь описать рассматриваемый феномен, пользовались самыми разными понятиями и терминами, такими, как «честь революционера», «революционная этика», «революционная традиция», «обычное право» революционера ${ }^{38}$ и т.п. Исследователи избегали не

38. Выражение докладчика по организационному вопросу на II съезде ПСР в феврале 1907 г., который подчеркивал, что усложнение внутреннего устройства и взаимоотношений в партии привело к тому, что «обычное право, если можно так выразиться, уже является недостаточным регулятором, необходимы иные регламентации, более общие» (Партия социалистов-революционеров: Документы и материалы, т. 1, М., 1996, с. 552) и слова Б.В. Савинкова в 1910 г. на заседании Судебно-Следственнной комиссии по делу Азефа (говоря об уставе БО ПСР и об ответственности ЦК ПСР он восклицал 
только как-либо типологизировать данное явление, но даже и называть его, предпочитая исследовать программы, тактику и деятельность революционных организаций и партий (хотя примечательно, что термин субкультура появляется в 30-е годы, но его не применяют к революционному движению). Одно из первых исключений - книга Б.И. Колоницкого «Символы власти и борьба за власть», где феномен хотя бы называется - «революционная традиция» и субкультура революционного подполья.

Предлагаем, на наш взгляд, более широкий и точный термин - «субкультура российского революционера», которая шире обоих вышеназванных терминов.

Социологи, культурологи, антропологи, этнографы давно уже успешно пользуются термином «субкультура», в том числе и в исследованиях тюремной субкультуры и молодежных контркультур. Среди последних сошлемся на книгу петербургского этнографа и социолога Т.Б. Щепанской «Система: тексты и традиции субкультуры», справедливо отмечающей, что:

отличие субкультур видят в том, что они неспособны к полностью автономному самовоспроизводству, используют коды своей культуры, из которой заимствуют символы, несколько их трансформируя или перекодируя. Каждая из субкультур определяет себя прежде всего по отношению к Культуре (господствующей, общепринятой, материнской и т.п.), противопоставляя ей свои нормы и ценности либо черпая в ней обоснования этих норм. ${ }^{39}$

Хронологические рамки существования субкультуры российского революционера, на наш взгляд, определяются моментом ее формирования на рубеже 50-60-х годов хІх в. и насильственным ее уничтожением вместе с ее носителями к концу $30-\mathrm{x}$ годов хх в. (последние очаги ее погасли в эмиграции). В то же время, на наш взгляд, прав был историк Андре Либих, писавший, что когда меньшевистский «<..> “Социалистический Вестник” закончил свое существование в американском изгнании в 1963 году, исчез последний кружок интеллигенции ХІХ века» ${ }^{40}$. Прибавим только, что не просто российской интеллигенции, а интеллигенции - носительницы субкультуры российского революционера.

Рассматривая субкультуру российской революционной среды с рубежа 50-60-х годов хіх в. до конца 30-х годов хх в., мы приходим к выводу, что и она была не общей и единой для всех и вся, а может быть признана нами как «рамочная», как некая абстракция, как термин. Пытаясь очертить контуры «субкультуры российского революционера», мы столкнемся с тем, что имеются серьезнейшие отличия не только «поколенческие», (т.е. между революционной субкультурой народников 70-х годов хІх века и субкультурой эсеров и меньшевиков, поддерживавших ее и живших в ней на рубеже 20-

- «Опять Центральный Комитет молчаливо одобрил если не тот формальный устав, который был принят, то обычное право, которое, собственно говоря, в этих вопросах совершенно соответствовало этому уставу» (См.: К.Н. Морозов, Партия социалистовреволюционеров в 1907-1914 г2., с. 175-176).

39. Т.Б. Щепанская, Система: тексты и традиции субкультуры, М.: ОГИ, 2004, с. 28.

40. «Указатели журнала «Социалистический вестник» :1921-1963»,в Социалистический вестник: Сборник: 1964-1965, Paris, 1992, с. XVIII. 
30-х годов хх в.), но даже и в рамках одного поколения - на уровне партийногруппового позиционирования. Так, современники отмечали наличие нескольких устойчивых социально-психологических типов революционеров (эсеры, анархисты, с.-д.), порой имевших также внутреннюю градацию ${ }^{41}$.

Различия в ментальности и темпераменте накладывали отпечаток на все - от политической тактики до бытовых мелочей и «тюремной тактики». Многое поможет понять отрывок из воспоминаний эсерки Е.Л. Олицкой, попавшей в 1924 г. на Соловки и сравнивавшей поведение в одинаковых условия заключенных эсеров и меньшевиков:

Я чувствовала, что между фракцией эсеров и с.-д. какая-то отчужденность. $<\ldots>$ Помогла мне Александра Ипполитовна [Щесневская].

- <..> Эсеры и социал-демократы не просто разные партии. Люди, примкнувшие к этим партиям, резко отличаются друг от друга. Они разные по складу мышления, по взглядам, по образу жизни. Мы говорим “типичный эсер" или "типичный социал-демократ” (выделено нами - К.М.). В тюрьме эти различия особенно выпирают наружу. ${ }^{42}$

Характерно и противопоставление В.М. Черновым В.И. Ленина как харизматического лидера и вождя партии себе и Г.А. Гершуни - как представителям разных типов российской революционной интеллигенции ${ }^{43}$. Но еще больший интерес для целей нашего исследования представляет черновая запись Чернова, где, противопоставляя себя Ленину, он говорит о себе в третьем лице:

Ленин и Чернов, как психологические и морально-политические типы, были, действительно, эквивалентны представляемым ими партиям. Оба, как типы, были глубоко национальны. Но в них воплощены были разные, и можно сказать, даже полярно-противоположные стороны национального русского характера. ${ }^{44}$

Мы имеем много свидетельств, как сильно отличались социалисты разных партий по темпераменту. Самыми рассудочными, осторожными, склонными больше к словам, чем к действиям в революционном движении считались меньшевики ${ }^{45}$. А самыми бесшабашными и склонными к авантюризму, с самым ярким революционным темпераментом считались (по убыванию) анархисты, максималисты, левые эсеры, эсеры и большевики (в 1917 г. большевики удивили всех, побив все рекорды). Последние, кроме того, отличались фанатичной уверенностью в собственной правоте и ненавистью к «тем, кто не с нами». Эту характерную черту большевизма отмечал в 1949 г. меньшевикэмигрант Г.Я. Аронсон, считавший, что «на этой ненависти, как на дрожжах, взошел впоследствии весь сталинизм» ${ }^{46}$.

41. См.: И.М. Майский, Демократическая контрреволюция, М.; Пг., 1923; Е.Л. Олицкая, Мои воспоминания, Франкфурт-на-Майне, 1971, т. 1, с. 241-243.

42. Олицкая, Мои воспоминания, т. 1, с. 241-243.

43. ГАРФ, ф. 5847, оп. 1, д. 66, л. 102-103 об.

44. ГАРФ, ф. 5847 , оп. 1 , д. 67 , л. 259.

45. См., например: А. Голубков, На два фронта, М., 1933, с. 21.

46. Г. Аронсон, «Меньшевизм (Опыт характеристики)», Социалистический Вестник, 1949, № 10 (625), с. 179. 
Но существовала и другая тенденция: люди из разных партий притягивались друг к другу, объединяемые общей идеей, стремлением перешагнуть через узкие партийные рамки. М.М. Чернавский, присутствовавший при разговоре Савинкова и Плеханова о необходимости сближения российских социалистических партий, происходившем в 1911 г. в доме последнего в Сан-Ремо, вспоминал:

<...> весь вечер у меня в голове вертелся вопрос: какой магнит притягивает друг к другу этих двух совершенно не похожих людей. Что это герои из совершенно разных опер, для меня было ясно, как день, несмотря на некоторые черты сходства между ними: оба революционеры, талантливые люди с большим характером. В то же время я не сумел бы словесно формулировать, в чем состоит это несходство. Принадлежность к разным партиям в данном случае не имеет ни малейшего значения. Можно набрать из различных партий сколько угодно людей, похожих друг на друга, как два новеньких пятиалтынных. ${ }^{47}$

Впрочем, и внутри партий было достаточно большое разнообразие «типов», порой гораздо больше не схожих друг с другом, чем с родственными им «типами» из другой партии. Так, по темпераменту один из главных эсеровских типов (решительный и боевой) был близок большевикам, а другой (народолюбивый рефлексирующий интеллигент) вызывал у большевиков полное отторжение и презрение. В этом контексте примечательна характеристика, выданная видному эсеру В.М. Зензинову секретным сотрудником ИНО ГПУ в 1922 г.: «Типичный член Авксентьевской Директории - бесхарактерный, нерешительный и недалекий. <..> Неустойчив, в политике недальновиден, типичный нерешительный русский интеллигент. Все сказанное не мешает ему считать себя искренним социалистом (выделено нами - K.M.)» ${ }^{48}$. Для коммунистов, считавших, что только они могут претендовать на звание истинного российского революционера и социалиста, слова «типичный нерешительный русский интеллигент», безусловно, были приговором для революционера, ставящим под сомнение право «считать себя искренним социалистом».

Вероятно, очень существенной причиной для «расселения по углам» в общей партийной «комнате» являлся темперамент и волевые качества людей, большая или меньшая рассудочность, или, напротив, склонность к прямому активному действию, а то уж и вовсе склонность к волюнтаризму и т.д. Так, в годы революции 1905-1907 гг. от эсеров откололись максималисты, во многом предвосхитившие эксперименты большевиков в 1917 г., а в 1917 г. в ПСР кроме эсеров центра (собственно эсеров) появились «левые эсеры», по темпераменту близкие к максималистам и большевикам, и «правые» эсеры типа Н.Д. Авксентьева, В.В. Руднева, И.И. Фондаминского, М.В. Вишняка, обладавшие совершенно иной физиономией. В 1921 г. Чернов скажет «правым» эсерам: мы по отношению друг к другу варвары, говорящие на разных языках.

47. М.М. Чернавский, «К характеристике Г.В.Плеханова (Отрывок из воспоминаний)», Историко-революционный бюллетень, 1922, № 2-3, с. 25.

48. ЦА ФСБ РФ, Н-1789, т. 63, л. 88-88об. 
Еще в 1910 г. Чернов говорил только о максималистах (то же самое можно было бы сказать и десять лет спустя о левых эсерах):

Многие элементы, характеризующиеся нетерпеливым, резко-революционным и непримиримым темпераментом, которым естественнее всего было бы примкнуть к анархизму, шли в ряды ПСР, моральный и политический престиж которой был высоко поднят в глазах публики рядом громких деяний. $<\ldots>$ Онито и явились впоследствии в партии теми центробежными силами, которым не хватало только лидеров для того, чтобы выделиться в особую фракцию или даже в новую партию. ${ }^{49}$

Взгляды и субкультура «правых» эсеров не сложились в нечто цельное, фиксированное на бумаге (несмотря на огромное количество статей, написанных ими в эмиграции). В этом видится одна из причин того, что ни современники, ни историки не могли вразумительно объяснить, что же из себя представляет «правый эсер». В свое время это попытался сделать Вишняк, у которого получилось пространное, патетическое и весьма расплывчатое определение. По его словам,

$<\ldots>$ правый эсер - не сторонник лозунгов «все или ничего», «сейчас или никогда», он не абсолютизирует какое-либо одно начало, исключающее все другие, не является ни догматиком, ни тем более фанатиком, не претендует на собственную непогрешимость.

Правый эсер чужд пафоса разрушения. Правый эсер считает, что противникам следует «раскрывать глаза, а не вырывать их». Правый эсер «исполнен стремления к свободе, напоен ее пафосом», являясь народником и идеалистом, признающим общественные нужды и цели стоящими выше личных. «Идеологически правый эсер считает себя реалистом», признавая и «категорический императив» и критическую проверку разумом всех сторон жизни. Правый эсер - «патриот без шовинизма», он знает, где его родина, но он и интернацио-налист. ${ }^{50}$

Впрочем, ему же принадлежат строки, намного рельефнее показывающие феномен «правого эсерства». Вспоминая о 20-30-х годах, Вишняк писал:

Одной из характерных и существенных черт [правого крыла партии] было то, что мы не исходили от социализма, как основы основ или высшей и абсолютной ценности, а приходили к нему, как к следствию и выводу, логически и исторически вытекавшему из гуманизма, демократизма, свободолюбия, достоинства человека, социальной справедливости. $<\ldots>$ социализм перестал быть для нас катастрофичным, строящим новое на отрицании и противоположении всему предшествующему, обветшалому <...> Дух разрушения сменялся волей к творчеству и созиданию. Призыв к ненависти и классовой и национальной борьбе - зовом к солидарности, от класса исходящей и чрез солидарность нации к международному и общечеловеческому содружеству восходящей. ${ }^{51}$

В эсеровской партии складывался и еще один тип эсера и, наверное, даже еще один весьма специфический вариант эсеровской субкультуры, не похожий на

49. В. Чернов «К характеристике максимализма», Социалист-революционер, Париж, 1910, № 1, c. 178 .

50. См.: М. Вишняк «Памяти ушедших», Новый журнал, 1953, № 33, с. 287-289.

51. М.В. Вишняк, «Современные записки»: Воспоминания редактора, СПб.; Дюссельдорф, 1993, с. 182-183. 
базовый. Он формировался исподволь среди членов БО ПСР в 1903-1905 гг., находившихся в совершенно необычных, резко отличающихся от повседневной жизни т.н. партийных «массовиков» (пропагандистов, агитаторов, техников, комитетчиков и т.д.) условиях. Эта «субкультура», символом которой стал Савинков, стала объектом критики и травли даже в эсеровской среде, против нее ополчились и «старики», и «молодые», и «массовики» и даже ряд «террористов»- боевиков называли «революционными кавалергардами», критиковали за высокомерие, дух исключительности, отчужденность от остальной части партии (Чернов накануне Первой мировой войны даже придумал очень странный план ротации «боевиков» и «массовиков»), за игру в ницшеанство, бесконечные рассуждения о смерти, о праве на убийство, за богоискательские тенденции, наконец. Надосказать, чтонеприятиевэсеровской среде этого явления, которое можно назвать зачаточной субкультурой, ее травля и травля ее лидера и символа Савинкова отнюдь не способствовали ее расширению и привлечению новых адептов. Сам Савинков говорил, что «его только прощают». Идеи, мысли «Воспоминаний», «Коня бледного», «То, чего не было» (с 1908 по 1913 г.), высказанные Савинковым, сделали его еще больше объектом преследования - «оплевывателем революции», «мастером красного цеха» и т.д. и т.п. Более того, «Заключение ССК» в 1911 г. по делу Азефа основным виновником азефщины делало кавалергардский дух, исключительность, отсутствие контроля за Боевой Организации со стороны ЦК, что не могло не возмущать членов БО. ${ }^{52}$

Необходимо также подчеркнуть, что выработка норм общей, рамочной революционной субкультуры происходила в различных группах и на протяжении длительного времени, причем эти группы и в XIX и в ХX в. могли быть как более открытыми, так и более закрытыми, а некоторые из них имели прямо сектантский облик (кружок Ишутина, организация Нечаева).

Выступая на состоявшемся 14 декабря 1996 г. в «Мемориале» теоретическом семинаре «Субкультура оппозиционных движений в России ХІХ-ХХ вВ.» (в организации которого принял участие и автор данной книги) петербургский исследователь Лев Лурье высказал несколько весьма плодотворных мыслей, требующих, впрочем, и корректировок, и дальнейшего развития (цитируем по диктофонной записи):

Здесь полезным может оказаться методология изучения вообще любых закрытых обществ, обществ с отклоняющимся поведением - это могут быть и старообрядческие толки, и «воры в законе», т.е. некие группы, которые сплочены общей опасностью и поневоле должны общаться прежде всего друг с другом. Революционная субкультура очень сильна и она сильнее, чем какиелибо другие субкультуры, и она медленно разрушается. И то, что в юности и молодости появляется, консервируется на очень долгий период, т.е. это субкультура, которая вырастает, как молодежная контркультура и остается чуть ли не до седых волос, потому что в условиях опасности они как бы в юности герметизируются в этой кампании, потому что они оказываются в тюрьме с этими же людьми, и в подполье с этими же людьми, и в эмиграции с этими же 
людьми в инородной среде, они как какие-нибудь пятидесятники в Канаде или староверы в Калифорнии, они образуют как бы анклавы, культурные анклавы, культурные скиты.

На наш взгляд, нельзя согласиться с утверждением Льва Лурье, что революционная субкультура, созданная как молодежная контркультура, «медленно разрушается», и «герметизируется» по двум причинам. Так оно и было бы, если бы созданная молодежью 60-70-х годов субкультура не испытывала притока свежей крови, но в том-то и дело, что каждое поколение, толкаемое стремлением создать «молодежную контрркультуру», вносило что-то свое, новое, омолаживало эту субкультуру. Порой это шло в конфликтах между «отцами» и «детьми», иногда консенсус достигался, иногда нет (и тогда возникал очередной вариант субкультуры внутри уже существующей субкультуры, как, например, в случае с эсеровскими боевиками, о котором уже говорилось выше).

Именно молодежь не давала покоя «загерметизировавшимся» в своих взглядах и вкусах «старикам», она становилась своего рода «двигателем прогресса», она заставляла в спорах и дискуссиях добавлять «свое», «новое», что обеспечивало развитие, обновление субкультуры, придание ей адекватности новым реалиям, в которых молодежь и родилась и которые хотела учитывать. Этот процесс «обновления» был постоянным и касался многих вопросов. Так, например, в начале хх в. произошло любопытное столкновение эсеровских «стариков» и молодой эсеровской поросли из кружка т.н. «грызунов науки» (так их называл М.Р. Гоц ${ }^{53}$ ), «галлов» (О.С. Минор), или «германо-эсеровского выводка» (В.М. Чернов) - группы студентов, учившихся в 1899-1904 гг. в Берлинском, Галльском и Гейдельбергском университетах, состоявшей из А.Р. Гоца, Н.Д. Авксентьева, В.М. Зензинова, И.И. Фондаминского, В.В. Руднева, Д.О. Гавронского, М.О. Цейтлин и др. Центральной фигурой этого «выводка» был Авксентьев, чье лидерство признавали все члены этого, по словам Чернова, «целого кружка незаурядных людей, сыгравших немалую роль в истории партии социалистов-революционеров то как единое целое, то порознь» ${ }^{54}$. Члены кружка твердо решили, что прежде чем они уйдут с головой в партийную работу, они должны как следует к этому теоретически подготовиться. Большинство из них изучали философию и хотели «под народническую политическую программу и неонародническую философию» подвести «не столько Лаврова и Михайловского, сколько Канта и Риля» ${ }^{55}$. В 1903 г. после ареста Гершуни и разгрома целого ряда эсеровских организаций (в том числе саратовской, выполнявшей функции ЦК), когда многие руководители партии стали всерьез опасаться за ее судьбу, М.Р. Гоц и О.С. Минор, отправившись в Германию, попытались призвать «галлов» поехать в Россию спасти ситуацию. В 70-е или 80-е (когда среди революционеров эмиграция вообще считалась неприличной и рассматривалась как дезертирство) и даже в 90-е годы любой революционер, не желавший выглядеть малодушным, поехал

53. В.М. Чернов, Перед бурей: Воспоминания, Нью-Йорк, 1953, с. 186.

54. Там же, с. 189.

55. Там же, с. 190. 
бы в Россию. «Грызуны» же настояли на том, что для революции и партии будет полезным, если они продолжат учебу. И самое главное, что это сошло им с рук, и их не объявили ни эгоистами, ни дезертирами и трусами и т.п., а вскоре они сделали стремительную партийную карьеру за считанные годы. Чернов даже был склонен оправдывать «грызунов» ${ }^{56}$. То, что на их эксперименты с философией и социологией смотрели терпимо, объясняется атмосферой в эсеровской среде (сразу отметим, что социал-демократическая среда была значительнее менее терпима, и это затрудняло процессы адаптации «новых» идей и изменения субкультуры). А то, что приняли терпимо их отказ ехать в Россию, говорило о том, что «старики» оказались вынуждены «подстроиться» и придумать себе в утешение и самоуспокоение соображения о том, что неподчинившиеся в их понимании «святому» партийному долгу «грызуны», может быть, и правы.

В ряде случаев, впрочем, молодежь оказывалась солидарна со «стариками». Когда Савинков восстал против «позитивизма и рационализма» «старой» революционной морали, ему оказали сопротивление. Он во многом опередил эту среду и поднялся выше нее в рефлексии, готовности говорить нелицеприятное об изнанке жизни революционера и непонятном для большинства товарищей по партии желании «раскрепостить дух», что привело к отторжению и абсолютному непониманию. Но его взгляды потерпели поражение не только потому, что их в штыки встретили «старики», гораздо сильнее на это поражение повлияло то, что их не поняла и отвергла немалая часть молодежи, и Савинков стал «еретиком» в глазах и тех и других (за исключением нескольких человек, в том числе и видных эсеров Л.Э. Шишко, Чернова, И.И. Фондаминского и других, защищавших его). Уже в конце 70-х годов хх века эсерка Б.А. Бабина считала, что Б.В. Савинков обладал необходимыми качествами для роли вождя эсеровской партии, если бы он не взорвал свой имидж этическими поисками в «Коне Бледном» и «То, чего не было» и весьма резко отзывалась о Чернове:

Чернов не является для меня образцом социалиста. Талантливый теоретик, прекрасно писал, но в личной жизни вел себя недостойно социалиста. Во время революции лидер партии, министр земледелия, вместо того чтобы заниматься своим прямым делом, крутит роман и меняет жену - это недостойно. Как вождь он совсем не удовлетворял никаким требованиям, просто хороший теоретик. Вождем у нас мог быть Савинков, но он был совсем другой ориентации. И потом, это был совсем аморальный человек, у него не было этики. Помните, он проповедовал: «Почему нельзя убить мужа своей любовницы, но можно убить министра? Если вообще можно убить человека, то безразлично, кого и по каким мотивам. Это он нам преподнес в 1909 году. Вся наша эсеровская молодежь была глубоко возмущена.» ${ }^{57}$ Примечательно, что в голове Б.А. Бабиной (как и большинства других эсеров) этические поиски и «богоискательство» Б.В. Савинкова с позиций «морального максимализма» (термин В.М. Чернова)

56. Там же, с. 208.

57. «Беседа с Б.А. Бабиной», Минувщее: Исторический альманах, вып. 2, М.: Прогресс, Феникс, 1990. 
превращаются в ... убеждение, что Б.В. Савинкова «<...> был совсем аморальный человек, у него не было этики».

«Обновление» молодежью и взглядов и субкультуры во многом облегчалось тем, что шла ротация революционных кадров, когда многие старики просто уходили в личную жизнь. Кроме того, мы бы поставили совсем иной акцент, чем Лев Лурье, в вопросе о взаимосвязи и первичности «молодежной контркультуры» и революционной субкультуры. Представляется, что революционная молодежь 60-х и 70-х годов в поисках понимания окружающего мира и своего места в нем изначально создает то, что мы бы сейчас, в привычных для нас терминах, назвали «молодежной контркультурой». Но ее носители стали реализовывать себя в основном в общественно-политическом пространстве, именно это поприще и считали для себя главным (в отличие, скажем, от разных вариантов и конкретных форм «молодежной контркультуры» второй половины хх века).

Впрочем, это отнюдь не значит, что революционеры разных поколений не пытались «освоить» какие-либо другие сферы жизни, кроме общественно-политической. С одной стороны, была создана субкультура, диктовавшая революционеру и образ жизни, и формы досуга, и круг чтения, и поведенческие нормы, фактически регламентирующие его действия даже в таких вещах, как, скажем, посещение публичного дома или увлечение алкоголем, склонность к азартным играм, разгульный образ жизни и даже внешний вид и т.д. и т.п. С другой стороны, многие из них рассматривали свою субкультуру как своего рода базовую (или как прообраз) для создания культуры нового социалистического мира, культуры, которая станет синтезом их субкультуры и культуры «трудящегося народа». Совершенно не случайно в начале хх века были популярны идеи богостроительства и «пролетарской культуры». Но это было уделом наиболее «продвинутых», выражаясь языком современной молодежи. А для массы революционеров считалось аксиомой, что своей жизнью, своей борьбой, своей моралью и даже своим бытовым поведением они должны служить маяками, примерами для миллионов, прозябающих в нищете и вне «культуры».

Как представляется, революционная субкультура не только родилась как «молодежная контркультура», она в ядре своем таковой и оставалась. И тут уместно будет отметить, что революционная среда в целом все же всегда была молодежной. По свидетельству Л.Г. Дейча, в 1877 г. в среде революционеров возраст в 25-26 лет считался уже очень «почтенным» ${ }^{58}$. Но даже спустя три-пять десятилетий, когда заговорили о «революционных поколениях», о «революционных династиях», когда в руководстве революционных партий появилось много убеленных сединами «почтенных революционных старцев», когда появилась «бабушка» (Е.К. Брешко-Брешковская) и «дедушка» (Н.В. Чайковский, правда, из-за недостойного поведения на суде в 1908 г. потерявший это звание) «русской революции», средний возраст

58. Л.Г. Дейч, «Валерьян Осинский (К 50-летию его казни)», Каторга и ссылка, 1929, № 5 (54), c. 8 .. 
членов оппозиционных социалистических партий был весьма молодым, и применительно к эсерам составлял, по подсчетам историка М.И. Леонова, не более двадцати двух лет.

О том же самом говорит черновая запись одного из лидеров эсеровской партии Чернова, посвященная роли интеллигенции в революционных партиях: «Интеллигенция: цвет, сливки, доктринеры. До 20-25 лет» ${ }^{59}$. В этом контексте интересны имеющиеся в черновиках Чернова тезисы следующего содержания:

В обычное время - скелетообразующие кадры. Проф. революционер. Странств. апостол социализма, рыцарь, карающий насильников. В своем роде великолепный тип. Тюрьма - его университет. Допросы - экзамен на аттестат зрелости. Конспирация - быт. Состязание в ловкости и неуловимости с полицией - его спорт. Побеги из тюрьмы - эпизоды. Паспортная, динамитная, шифровальная техника - его профподготовка. Пропаганда и агитация - его жизнь. ${ }^{60}$

Весьма показательна и реплика, прозвучавшая на III Совете партии в июле 1907 г. (при обсуждении вопроса о профсоюзной работе) из уст эсера-обкомовца, представителя Закавказской области: «<..> возьмем возрастной состав: средний возраст герм[анских] с.-д. 30 лет, я член ОК - мне несколько больше $20{ }^{61}$. K «германским» возрастным стандартам с.-д. и с.-р. приближались только, когда речь шла о руководящих кругах этих партий (удельный вес интеллигенции также сразу во много раз возрастал).

Понять, как происходило в реальной жизни поддержание за молодежью численного перевеса в революционной среде, нам поможет обращение к опыту, поставленному самой жизнью после первой российской революции, хотя этот механизм работал и раныше и позже. После серьезных неудач и гибели «Народной Воли» в 80-х годах хІх в. в революционное движение пришла молодежь, из действующих «стариков» в России остались считанные единицы. В массе своей они были сосредоточены в эмиграции и «пущали революцию промеж собой», и лишь некоторые из них, выходя с поселений на рубеже хіххх вв., примыкали к «племени младому, незнакомому». Еще ярче это проявилось после первой российской революции, когда под влиянием самых разных причин, начиная с усталости, потери перспектив, страха правительственных репрессий и заканчивая гнетущим впечатлением от дела Азефа или разочарования в революционных лидерах, тысячи «старых» революционеров «ушли в личную жизнь», а многие оказались в эмиграции. Весной 1912 г. один из руководителей партии, А.А. Аргунов, обобщив весь материал, имевшийся в его распоряжении, сделал симптоматический вывод. Он писал:

Первое, что останавливает внимание, - это почти полное отсутствие в подполье нашей взрослой интеллигенции. Это наблюдается повсюду, констатируется в сообщениях с разных мест. «Нет опытных работников», «нет опыта», «учим-

59. ГАРФ, ф. 5847, оп. 1, д. 65, л. 112.

60. ГАРФ, ф. 5847, оп. 1, д. 67, л. 229.

61. МИСИ, Архив ПСР, 145. 
ся в процессе работы» - таков общий голос. За самым редким исключением, «опытные», «взрослые» и проч. товарищи стоят в стороне от подполья. ${ }^{62}$

Впрочем, бывшие партийные работники стояли в стороне и от легальной работы в различного рода «культурных учреждениях» ${ }^{63}$. Аргунов делал справедливое заключение:

Таким образом, главная тяжесть подпольной работы лежит на плечах молодежи, - преимущественно студенчества, да провинциальной молодой «разночинной» публики. На смену прежним руководителям движения явилась молодежь, работа в подполье ведется силами ее и передовой части рабочих и крестьян, при безучастном отношении взрослой опытной публики. ${ }^{64}$

Подобное повторилось и в 1923-1925 гг., когда студенческая молодежь, начав борьбу с властью за свои права и «университетскую автономию», судорожно искала социалистов, которые уже были в ссылках и политизоляторах, и очень хотела помощи и ответов на многие вопросы ${ }^{65}$.

Сломать этот механизм прихода молодежи в революционную среду удалось только в 30-40-е годы, с одной стороны, физическим уничтожением этой самой революционной среды, с другой - вбиванием в молодые головы недопустимости наличия у советской молодежи какой-либо «контркультуры». Но ни страх общественного осуждения, ни страх репрессий не смог прекратить естественного для молодежи процесса - обретения себя хоть в каком-то протесте. С 50-х годов он выплеснулся и в стилягах, и в увлечении западной музыкой, и конечно же, в попытках политического протеста, который в 4050-е годы шел в русле критики коммунистов с позиций классиков марксизмаленинизма, а позже, в 60-70-е годы, вылился в диссидентское движение и подпольные политические движения молодежи от черносотенного до прокоммунистических взглядов, но связь поколений к этому времени была уже разорвана.

Сильнейший отпечаток на революционную субкультуру наложило также то, что она всегда была гонимой, противозаконной, нелегальной ${ }^{66}$. В своих воспоминаниях Дейч уделил немало места размышлениям о причинах существования именно в России столь мощного слоя «нелегальных», о складывании традиций нелегального существования, о его плюсах и минусах. В качестве характерных черт «нелегала» он отмечал «постоянную привычку к опасностям, полное равнодушие к своему будущему, готовность в любой момент расстаться со свободой, а то и с самой жизнью», «стремление сделать

62. А. Кубов, «Голоса из подполья (Заметка)», Знамя труда, 1912, № 42, с. 11.

63. Кубов, «Голоса из подполья», с. 11.

64. Кубов, «Голоса из подполья», с. 11-13.

65. Олицкая, Мои воспоминания..., т. 1, с. 226.

66. Чернов подсчитал количество обысков, побегов, лет тюрьмы и т.д., пришедшееся на делегатов Лондонского съезда с.-д. и Лондонской конференции с.-р.: «Лондонский съезд с.-д. 338 чел. - 597 лет гласного надзора, тюрем, ссылки, каторги. Средний возраст 28 лет - 710 привлечений к делу, 201 побег. Лондонская конференция ПСР 61 чел. - 228 обысков, 146 попаданий в тюрьму, 121 год ссылки, 104 года тюрьмы, 88 лет каторги» (ГАРФ, ф. 5847, оп. 1, д. 67, л. 229). 
что-нибудь заметное, крупное, громкое», «жажду сильных ощущений, рискованных и опасных предприятий», готовность «в любой момент примкнуть к самому отчаянному предприятию, в котором ему нетрудно было сложить свою буйную голову» ${ }^{67}$.

К началу хх века, и особенно после революции 1905-1907 гг. квалификация полиции (и сеть ее секретных сотрудников) выросла настолько, что ни о каком многолетнем нахождении в качестве нелегального и речи уже не было ${ }^{68}$, но традиции «нелегального» были уже весьма крепки, да и само положение имело свои плюсы, не говоря уже о тех ситуациях, когда оно было абсолютно необходимым или вынужденным.

Как и за 30-40 лет до этого, нелегальная работа накладывала свой отпечаток на привычки и ментальность людей. Так, например, большевичка Е.Д. Стасова называла следующие необходимые, на ее взгляд, для находящегося на нелегальной партийной работе человека черты: точность, чтобы вовремя придти на встречу с товарищем или на явку; «наблюдательность, внимание к окружающему»; «умение владеть своим лицом», чтобы на допросе «ничем не выдать своих мыслей и чувств»; привычка «не спрашивать друг у друга о том, что тебя не касается» ${ }^{69}$.

Одним из ключевых системообразующих элементов сложившейся субкультуры может считаться система поведенческих норм, регулируемых «общественным мнением» социума, намечающим границы допустимого и недопустимого (и контролирующим соблюдение этих норм). Потребность для российских революционеров в подобном была вопросом выживания социума, что привело к постепенному созданию своеобразного «партийного правосудия». Нормы поведения революционера на следствии, в тюрьме, на суде (помогающие ему отличать грань допустимого в компромиссах для облегчения своей участи, с одной стороны, и предательства - с другой) и их мотивация, собственно говоря, и стали первым побудительным толчком к созданию того, что можно назвать своеобразным революционным «партийным правом». «Партийное правосудие» же вобрало в себя помимо правовых норм также конкретные механизмы и структуры следствия и суда. Кроме этого, важнейшей функцией партийного и внепартийного «товарищеского» следствия и суда являлись «восстановление чести» и защита достоинства революционера.

Генезис и развитие революционного права отразили в себе общие тенденции и источники генезиса и развития субкультуры российского революционера в целом,причем огромную рольигралиисоциальные источникиих формирования

67. Л.Г. Дейч, За полвека, т. 1, ч. 2, М., 1923, с. 27-30.

68. Весьма любопытно, что член Областного Бюро Северной областной организации ПСР, заявивший на V Совете партии, что партийный работник-непрофессионал может «психологически выдержать» только полгода, на заинтересованные вопросы ответил, что «убедился на опыте, что в Петербурге в течение 6 месяцев прошла полная смена всех работников, за исключением тех, которые едва-едва работали, и которые поэтому могут целый год числить себя партийными работниками» (МИСИ, Архив ПСР, 146).

69. Е.Д. Стасова, Страницы жизни и борьбы, 3-е изд., М., 1988, с. 56-57. 
и общественно- политические условия (взять хотя бы для примера периоды реакций и революций, немедленно накладывавших свой отпечаток на них). Если говорить о социальных источниках формирования революционной субкультуры и революционного права, то с одной стороны, они складывались под сильным и, пожалуй, даже доминантным влиянием дворянской культуры, в том числе и игравших в ней ключевую роль т.н. «законов чести», с другой, участвовавшие в революционном движении представители самых различных классов и социальных слоёв общества также весьма ощутимо влияли на формирование правосознания, норм поведения и практики революционера.

Первая серьезная встреча революционных партий и широких масс произошла во время революции 1905-1907гг., и хотя лозунги и идеи партий были поддержаны, а сами они превратились в массовые партии, эту встречу нельзя назвать однозначно успешной. Она выявила серьезные проблемы и противоречия как с одной, так и с другой стороны. Перефразируя слова Ленина, называвшего революцию 1905-1907 гг. репетицией революционного взрыва 1917 г., можно сказать, что революция 1905-1907 гг. была репетицией экзамена как для народа, так и для партий, взявшихся выражать его интересы. Экзамена на политическую зрелость и дальновидность, экзамена, с треском проваленного между Февралем и Октябрем - и ПСР и народными массами.

ПСР - потому, что она оказалась не на высоте исторических вызовов времени и желаний революционизированных масс. А.Р. Гоц двадцать лет спустя в тюрьме справедливо восклицал, что эсеры и меньшевики в 1917 г. уподобились «<... анекдотическому прапорщику, утверждавшему, что вся рота идет не в ногу, а только он один идет в ногу, с.-р. и меньшевики упорно настаивали на правильности своей политической линии и наперекор очевидным фактам. Дантон в Великую французскую революцию говорил, что [нужно] уметь не только вести за собой народ, но и следовать за ним в тот или иной момент» ${ }^{70}$.

Народные массы - потому, что в силу недостатка политической культуры и дальновидности не разглядели за обещаниями большевиков воплотить в жизнь их мечтания лика диктаторов и безжалостных авантюристичных экпериментаторов над собственным народом.

Научно-информационный и просветительский центр (НИПС) «Мемориал»

mak92@internets.ru 